\section{AN ADDRESS ON DISENFECTION AND DISINFESTATION IN THE FIELD.}

Delivered at the Inaugural Meeting of the Section of Military Hygiene of the Society of Medical Officers of Health.

By W. W. O. Beveridge, C.B., D.S.O. K.H.P., M.B., M.Ch., D.P.H., BrigadierGeneral, A.M.S.

\section{II.-Disinfestation.}

\section{(Concluded from page 63.)}

Early in the war efforts were made to provide divisional baths, where the men on return from the trenches could take hot baths, be supplied with clean underclothing and at the same time have all their clothing disinfester. One of the first of these baths was installed at Nieppe by Colonel O'Callaghan in some dye works, the vats being used as baths. Unfortunately the Germans got wind of them, and they were destroyed by shell fire, the men engaged in bathing at the time escaping without their clothes. Other divisions quickly provided themselves with baths, situated either in factories or similar buildings, or special accommodation erected by the Royal Engineers.

Disinfestation of clothing was carricd out either by steam, or by pressing the seams of the outer clothing with hot irons. It was quickly recognised that steam disinfection had many disadvantages and attempts were made to replace steam by hot air. The disadvantages of steam are that unless it is available as in laundries, special boilers are required, and the necessary fuel is at times not forthcoming. Secondly, clothes - especially outer clothingare liable to shrink and crease when compressed in the chambers. Drying in special machines takes time, and in extemporised apparatus more especially in wet weather, immediate thorough drying is almost an impossibility.

Hot AIR DisinfeCTORS.

The high standard of efficiency which is necessary in the case of regular steam disinfectors to destroy bacteria and their spores is not required to destroy vermin, and therefore the simpler and less costly hot air disinfectors, working at a lower temperaturc, are more suitable for the destruction of vermin in the field. From the point of view of louse destruction alone, it was apparent that if the difficulties attending the circulation of hot air in the chamber could be overcome so that all parts of the clothing would be exposed to an equal temperature, then hot air disinfectation would prove the better method, for the following reasons:-

I. The neccssary lethal temperature is easily obtained by means of any available fuel such as coke or wood. In France we relied upon a temperature of from $75-80^{\circ} \mathrm{C}$., maintained for twenty minutes with perfect success by means of burning coke.

2. No shrinkage or creasing of the clothing occurs. Clothes are not spoilt in any way as long as the temperature does not exceed $I 10^{\circ} \mathrm{C}$., and buttons and badges are not tarnished.

3. No drying of the clothing is required, and men are issued with dry warm clothing, which is a real comfort in the field.

4. Perfect efficiency. No risk whatsoever of lice and their ova not being destroyed in well -constructed plants.

5. Thre process is much more rapid than that of steam, as no after-drying is necessary.

6. Any article of clothing can be dealt with, including riding breeches, leather, gum boots and other articles of clothing and equipment which are liable to be injuriously affected by steam.

7. The cost of construction and expense of working is considerably less than when steam is employed.

8. Most of the types can readily be made from material available, such as corrugated iron, rails, etc.

\section{MAJOR ORR'S DISINFECTOR.}

To Major Orr of the Canadian Medical Service belongs the credit of having designed a plant which fulfilled all these requirements, and in which sufficient means were arranged for circulating the air and so conveying a uniform tcmperature throughout the chamber. This type of apparatus was extensively used in the First Army area and also in various camps and bases, with excellent results. Lice and their nits were baked as hard as biscuits within the space of twenty minutes. It was also the type used in connection with bathing establishments for men on demobilisation. Major Orr's hot-air disinfector can briefly be described as follows:--

The disinfecting chamber, which measures fifteen feet long, eight feet wide, and six feet high inside, is constructed over a pit with sloping sides measuring seven feet by fourteen feet at the top and five feet by ten feet at the bottom; a stairway at one side leads to the entrance of the pit, which is closed by a tightlyfitting metal door. Two special constructed 
braziers twenty-four inches in diameter, each capable of holding 120-125 lbs. of coke, are placed in the pit. Air is supplied to the braziers by two four-inch pipes which enter the chamber at each side of the door, and open directly beneath the braziers. The floor of the chamber over the pit consists of corrugated iron perforated with 126 openings, each three inches by six inches. Three four-inch right angle air outlet pipes extend through each of the side walls close to the ceiling. These outlet pipes in conjunction with the air inlet pipes beneath the braziers provide for the circulation of hot air and gases through the chamber. The front of the chamber consists of two double tightly-fitting doors, made of wood insulated with asbestos or metal, or of metal alone. The clothing for disinfectation is hung on specially constructed trucks or trolleys which can be moved into and out of the chamber on light railway lines. Each truck carries 128 articles of clothing or blankets. The fuel consumption amounts to about $200 \mathrm{lbs}$ per day, and the braziers after starting require no further attention, except sometimes the addition of a little coke at noon.

Disinfectation is completed when the clothing has been exposed to a temperature of $75^{\circ} \mathrm{C}$. for twenty minutes. It was found by experiment that as the temperature beneath the folds of the garments was from ro- $15^{\circ}$ below that of the surrounding air of the chamber; it was therefore necessary to expose the articles for twenty minutes to a temperature above $75^{\circ} \mathrm{C}$. (as indicated by a $L$ thermometer supplied and fixed to the chamber) to ensure certainty of disinfectation.

\section{RUSSIAN PIT DISENFECTOR.}

This very serviceable and efficient form of hot "air disinfector, simple to construct and easy to work, was brought to my notice by General Sir William Macpherson. This form was extensively used in the Fourth Army, and in many labour and prisoner of war camps.

It consists of a chamber eight feet long, six feet wide, and seven feet deep, ding in the ground and roofed in with corrugated iron, suitably supported. A layer of earth is spread over the roof. Access to the chamber is gained by an entrance two feet wide extending from the roof to the floor at the middle of the longer side of the chamber, closed by a corrugated iron door fitted in grooves. Two simple stoves made out of nil drums placed in each of the far corners of the chamber supply the heat.
These are stoked from above, through the Hues, which leads upwards through the roof to about two feet above the layer of earth. Clothes after being turned inside out are suspended on wires strung across the chamber. Disinfectation is completed in from thirty to sixty minutes, and a temperature of $90^{\circ} \mathrm{C}$. can be obtained in the centre of the chamber. Air is best supplied by means of ducts carried from the well of the entrance under the floor of the chamber and opening directly beneath the stoves. About 200 blankets or 100 kits can be dealt with at one time. This type of disinfector was however, not suitable where the ground water approached the surface, as in the Ypres salient.

Conclusion: Scheme for General DeMOBILISATION.

In conclusion, I should like to say a few words concerning the arrangements for cleansing the men and for disinfecting their clothing on demobilisation at base ports immediately before they embarked for England. The necessity for such a procedure is obvious. In the interests of the civilian population at home, as well as of the men themselves, it was imperative that the men should leave France clean and free from vermin. I was asked to draw up plans for cleasing establishments to include bathing and disinfectation arrangements for 3,000 men per. diem at each port of embarkation at least eighteen months before the armistice. The plans were approved, but owing to the favourable opinion I had formed of the hot air disinfector designed by Major Orr, the latter was substituted for the steam type of apparatus originally proposed. The uninterrupted success of the hot air system justified my action, and doubtless the problem of disinfectation in the field can now be said to have been solved.

Owing to the large number of men to be dealt with in a limited time on general demobilisation, it was considered advisable that sanitary precautions as to cleansing and disinfection of clothing should be carried out on a comprehensive scale at each centre of demobilisation, immediately prior to embarkation. Centres for demobilisation were arranged in connection with the various ports of embarkation. These camps received the numbers of men allotted to embark on any one day; they were divided into "a dirty section" and "a clean section," between which cleansing stations were interposed. The men on arrival 
proceeded to the dirty section, and after being bathed and then disinfected at the cleansing station moved into the clean section, where they remained until they embarked for Eng. land. Each complete cleansing installation was designed to provide for the bathing and disinfection of the clothes of 3,000 men in from Io to I I hours. These installations were provided on a basis for dealing with 50 per cent more men than the camp accommodated to allow for breakdowns and overlapping. The bathing arrangements included dressing rooms, hot sprays (24 per 3,000 men per day), and drying rooms, with accessories such as towel rooms, dirty underclothing and clean underclothing stores. Bathing and disinfection could be carried out simultaneously throughout the day.

For disinfection the hot-air disinfector designed by Major Orr, of the Canadian Army Medical Service, was adopted. This type of disinfector was highly efficient and satisfactory in working owing to the continual passage of a current of hot air through the chambers. On account of the low specific heat of air a rapid circulation of hot air is necessary to raise the temperature of the clothing to the lethal temperature within a reasonable time. The articles to be disinfected for each man were: (1) tunic, (2) trousers, (3) shirt, (4) vest, (5) greatcoat. The men were supplied with clean underclothing, of which a stock of 12,000 pieces was kept at the cleansing station. The underclothes worn by the men on arrival at the baths, such as shirts, undervests and pants, were despatched to area laundries, where they were disinfected in steam chambers, washed, and returned to the cleansing station for reissue.

The men brought down their blankets with them, and these were disinfected and re-issued to the camps. The blankets used in the dirty section of the camps were disinfected at least once a week, or oftener, if in the opinion of the Medical Officer it was considered necessary. In the clean section, the blankets were also disinfected weekly. Facilities for disinfecting the blankets were afforded by working the hot air disinfectors during the night hours. At any one installation, 3,000 blankets could be disinfected in 3 to 4 hours, allowing at least half an hour in the disinfecting chambers. Medical inspection was carried out as the men passed through the baths by a medical officer, and cases of scabies or other diseases were sent to a hospital specially allotfed to receive men from camps of demobilisation. As the stay in camp was liable to be tedious, sports, games and other recreations and entertainments were organised.

\section{THE REFRACTORIES INDUSTRIES (SILICOSIS) SCHEME, I9I9.}

By Chas. L. Sutherland, M.B., D.P.H., District Tuberculosis Officer, Yorks, West Riding.

The Refractories Industries (Silicosis) Scheme was brought into force under the Workmen's Compensation (Silicosis) Act, Igrg. At present it provides for compensation in one class of workers only, that of miners in ganister and workers in silica brick works. As there is a likelihood of this or some similar scheme being extended to other workers exposed to dust-discases, it may interest your readers to go over some of the points in connection with the present scheme. I do not propose to go into the clinical aspects of the question.

The finance of the Scheme is dealt with by a limited company called the "Fund," which is supported by contributions from the employers, each employer paying on the basis of a percentage of the wages earned by the employees covered. All those firms who deal with materal containing 80 per cent of silica are brought within the Scheme.

It is to be noted that the Scheme is the first attempt to avoid the County Courts in compensation cases. The compensation is fixed by a committee composed of equal numbers of workmen and employers under a neutral chairman. To this committee the "Appointed Medical Officer" sends the certificates of disability; and these certificates are final in that they cannot be challenged and the matter taken to court.

Work under the Scheme falls upon the Tuberculosis Officer of the area, who becomes the appointed medical officer. His duties during the first year of the operation of the Scheme have been to examine all workers in the industries, to examine all new workers, and to examine all claimants for compensation. The medical officer has to suspend any worker whom he believes to be suffering from silicosis to a degree that would be dangerous if he continued at the vork. To assist him on this point he may make use of the X-ray, and if still in 